\title{
Cross-linked enzyme crystals of organophosphate hydrolase for electrochemical detection of organophosphorus compounds
}

\author{
Thanaporn Laothanachareon • Verawat Champreda • \\ Pornpimol Sritongkham · Mithran Somasundrum • \\ Werasak Surareungchai
}

Received: 2 July 2008/Accepted: 27 August 2008/Published online: 24 September 2008

(c) The Author(s) 2008. This article is published with open access at Springerlink.com

\begin{abstract}
Cross-linked enzyme crystals of organophosphate hydrolase (CLEC-OPH) prepared from crude recombinant $E$. coli cell lysate was used for the development of an electrochemical biosensor for the detection of organophosphate pesticides. CLEC-OPH showed an increased $V_{\max }$ of $0.721 \mathrm{U} \mathrm{mg}$ protein ${ }^{-1}$ and a slightly lower $K_{\mathrm{m}}$ of $0.083 \mathrm{mM}$ on paraoxon compared to the crude enzyme, resulting in an improved catalytic efficiency $\left(k_{\text {cat }} t\right.$ $K_{\mathrm{m}}=4.17 \times 10^{5} \mathrm{M}^{-1} \mathrm{~min}^{-1}$ ) with a remarkable increase on thermostability. An amperometric biosensor was constructed based on glutaraldehyde and albumin crosslinkage of CLEC-OPH with carbon nanotubes. The sensor exhibited greater sensitivity and operational stability with a lower limit of detection when compared with a sensor using an equivalent loading of crude OPH in a non-crystal form. The application of crude enzyme-based CLEC would offer a simple and economical approach for the fabrication of efficient electrochemical biosensors.
\end{abstract}

Keywords Biosensor - Cross-linked enzyme crystal . Organophosphate hydrolase $\cdot$ Paraoxon

T. Laothanachareon · W. Surareungchai $(\bowtie)$

School of Bioresources and Technology, King Mongkut's

University of Technology Thonburi,

Bangkhuntien, Bangkok 10150, Thailand

e-mail: werasak.sur@kmutt.ac.th

V. Champreda $(\varangle) \cdot$ M. Somasundrum

Enzyme Technology Laboratory, National Center for Genetic

Engineering and Biotechnology (BIOTEC),

Thailand Science Park, Pathumthani 12120, Thailand

e-mail: verawat@biotec.or.th

P. Sritongkham · M. Somasundrum

PDTI, King Mongkut's University of Technology Thonburi,

Bangkhuntien, Bangkok 10150, Thailand

\section{Introduction}

Enzyme stabilization is essential for efficient biotechnological application of biocatalysts in a number of research and development fields. Among many methodologies developed for stabilization of enzymes, cross-linked enzyme crystal (CLEC) technology has recently received great attention. CLEC preparation includes crystallization of enzymes into microcrystals and subsequent cross-linking with homobifunctional or heterobifunctional reagents (Margolin and Navia 2001). Due to stabilization of the enzyme's active conformation in three-dimensional crystal structure, the microcrystalline enzymes offer many advantages, including improved thermostability, physical stability and tolerance to organic solvents, with an increase on volumetric activity (Roy and Abraham 2004). CLEC is thus considered a simple and cost-effective approach for preparation of enzymes for a range of biocatalytic applications, including organic synthesis, starch saccharification, and biosensors.

Application of CLECs in biosensor application have been reported using glucose oxidase (Mattos et al. 2001), urease (Navia and St. Clair 1999), horseradish peroxidase (Roy and Abraham 2004), and recently with laccase (Roy et al. 2005), for detection of compounds of medical and environmental importance. Compared to conventional immobilization of enzyme on electrode, CLECs exhibit increased sensitivity and stability. The application of CLECs for biosensor is thus of great interest.

Organophosphate hydrolase (OPH) is an organophosphorus hydrolyzing enzyme, first discovered in soil microorganisms, Pseudomonas diminuta (Dumas et al. 1989 and Flavobacterium sp. (Mulbry and Karns 1989b). The enzyme is specific to ester bond hydrolysis in a range of neurotoxic organophosphate pesticides, including paraoxon, 
parathion, methyl-parathion, coumaphos and chemical warfare agents, sarin and soman, releasing the electroactive $p$-nitrophenol (PNP) as the product. Several types of biosensor using OPH for detection of organophosphate compounds have been developed, based on optical (Mulchandani et al. 1999b; Rogers et al. 1999; Simonian et al. 2005), potentiometric (Mulchandani et al. 1999c), and amperometric (Mulchandani et al. 2001; Chough et al. 2002; Wang et al. 2003; Deo et al. 2005) detection. However, the commercial application of OPH-biosensor has been impeded by several factors, including high cost on enzyme production, purification and processing.

In this work, the simple preparation and kinetic study of the crude enzyme-based CLECs is described. Application of CLEC-OPH was compared for analytical utility to the conventional cross-linked form in amperometric detection of organophosphorus compounds. This report demonstrates the potential of using crude enzyme-based CLECs as costeffective biocatalysts for further development of efficient electrochemical biosensors.

\section{Materials and methods}

\section{Reagents and chemicals}

Ampicillin, chloramphenicol and glutaraldehyde were obtained from Fluka. Isopropyl $\beta$-D-1-thiogalactopyranoside (IPTG) and DNaseI were purchased from Fermentas (Vilnius, Lithuania). Phenylmethane sulfonylfluoride (PMSF) was supplied from Bio-Rad (Hercules, CA). Bovine serum albumin (BSA) was obtained from Sigma. Paraoxon was acquired from Supelco (Bellefonte, Pennsylvania). Solvents were analytical grade including isopropanol (Merck, Whitehouse Station, NJ) and $\mathrm{N}, \mathrm{N}$ dimethylformamide (DMF) (Ajax Finechem, Seven Hills, Australia). Multi-walled carbon nanotubes (MWNTs) was purchased from MER Corporation (Tucson, Arizona). All chemicals were used as received without further purification. All solutions were made in double distilled water.

Preparation of crude recombinant $\mathrm{OPH}$

The 1.1-kbs opd gene was amplified from the indigenous plasmid of Flavobacterium sp. ATCC27551 and cloned into pET-32a (Novagen, Darmstadt, Germany) at the NcoI and XhoI sites. The resultant plasmid, pTOPD, was transformed into a protease deficient host, $E$. coli Rosetta(DE3)(pLysS) (Novagen) for recombinant enzyme expression. The recombinant $E$. coli was grown in Luria Bertani broth (LB) ( $1 \%$ tryptone, $0.5 \%$ yeast extract, and $1 \% \mathrm{NaCl}$ ), supplemented with $100 \mu \mathrm{g} / \mathrm{ml}$ ampicillin and $25 \mu \mathrm{g} / \mathrm{ml}$ chloramphenicol for overnight with shaking at $37^{\circ} \mathrm{C}$. One percent $(\mathrm{v} / \mathrm{v})$ culture was inoculated into a fresh medium with the same composition and incubation condition. When the cell reached the mid-log phase $\left(\mathrm{OD}_{600}=0.5-0.6\right)$, $0.5 \mathrm{mM}$ IPTG (final concentration) was added to induce the recombinant enzyme expression, and $50 \mu \mathrm{M} \mathrm{CoCl}_{2}$ was used as a supplement. The cells were cultured in an orbital shaker at $18^{\circ} \mathrm{C}, 200 \mathrm{rpm}$ for $8 \mathrm{~h}$. Cell pellet was harvested by centrifugation at $9,000 \times g$ for $10 \mathrm{~min}$, and then resuspended in a lysis buffer (50 mM Tris- $\mathrm{HCl}(\mathrm{pH} 8.0), 50 \mu \mathrm{M}$ $\mathrm{CoCl}_{2}, 2.5 \%$ Triton X-100, $5 \mathrm{mM}$ PMSF and $10 \mu \mathrm{g} / \mathrm{ml}$ DNaseI). The cell suspension was cooled on ice and passed through a French Pressure cell (1,500 psi). The cell lysate was clarified by centrifugation at $9,000 \times g, 4^{\circ} \mathrm{C}$ for $10 \mathrm{~min}$. The supernatant containing OPH activity was concentrated and transferred to $50 \mathrm{mM}$ Tris- $\mathrm{HCl}$ buffer ( $\mathrm{pH}$ 8.0) by ultrafiltration using Amicon ultrafiltration unit (10 kDa MWCO) (Millipore, Billerica, MA) and used as the crude $\mathrm{OPH}$ for further experiments.

\section{Crystallization of $\mathrm{OPH}$}

Crude OPH was crystallized by batch method based on the condition previously reported (Roy and Abraham 2006). Ammonium sulfate in small portions was added to the crude $\mathrm{OPH}(20 \mathrm{mg} / \mathrm{ml})$ in $50 \mathrm{mM}$ Tris- $\mathrm{HCl}$ buffer (pH 8.0) to reach $75 \%$ saturation over $3 \mathrm{~h}$ by stirring at $4^{\circ} \mathrm{C}$. The supersaturated solution was kept at this temperature, undisturbed for $20 \mathrm{~h}$. The enzyme crystals formed were separated by centrifugation at $500 \times g$ for $8 \mathrm{~min}$ and washed with isopropanol to remove the excess ammonium sulfate. For cross-linking reaction, $20 \mathrm{mg}$ of OPH crystals was reacted with $2 \mathrm{ml}$ of $1.5 \% \mathrm{v} / \mathrm{v}$ glutaraldehyde solution in isopropanol for $20 \mathrm{~min}$ at room temperature. After crosslinking, the enzyme crystals (CLEC-OPH) were washed three times with $50 \mathrm{mM}$ Tris- $\mathrm{HCl}(\mathrm{pH} 8.0)$ to remove the excess glutaraldehyde and stored in the same buffer for further experiments.

Spectroscopic activity assay of soluble OPH

Organophosphate hydrolase activity of the soluble crude $\mathrm{OPH}$ was measured spectrophotometrically by monitoring the production of $p$-nitrophenolate. The standard assay reactions of $1 \mathrm{ml}$ contained $0.5 \mathrm{mM}$ paraoxon in $100 \mathrm{mM}$ sodium phosphate buffer $(\mathrm{pH} 8.0$ ), and an appropriate dilution of $\mathrm{OPH}$ was added to start the reaction. The assay reaction was incubated at $25^{\circ} \mathrm{C}$. The rate of $p$-nitrophenolate formation was calculated from the measurement of $\mathrm{OD}_{400}$ at time intervals in the period of $3 \mathrm{~min}$ $\left(\varepsilon=17,000 \mathrm{M}^{-1} \mathrm{~cm}^{-1}\right)$. One unit of enzymatic activity was defined as the amount of enzyme capable to catalyzing the production of $1 \mu \mathrm{mol}$ of $p$-nitrophenolate per minute under the standard conditions. 
Spectroscopic activity assay of CLEC-OPH

The assay reaction of 1-ml total volume contained $0.25 \mathrm{mM}$ paraoxon in $100 \mathrm{mM}$ sodium phosphate buffer (pH 8.0). CLEC-OPH $\left(1.22 \times 10^{-3} \mathrm{U}\right)$ was added to the assay reaction and stirred continuously for $5 \mathrm{~min}$. The increase in absorbance was monitored at $30 \mathrm{~s}$ and at definite time intervals at $400 \mathrm{~nm}$.

\section{Kinetic parameter analysis}

Kinetic parameters of the crude soluble OPH and CLEC$\mathrm{OPH}$ were determined under the standard assay conditions with varying paraoxon concentration, while keeping the concentration of the biocatalyst constant. The MichaelisMenten constant $\left(K_{\mathrm{m}}\right)$ and maximum velocity $\left(V_{\max }\right)$ were calculated from the data obtained fitted by linear least square regression.

\section{Determination of protein}

The concentration of protein in the soluble crude enzyme and CLEC was determined using Lowry's method according to Abraham et al. 2004 (Abraham et al. 2004; Rajan and Abraham 2007). Bovine serum albumin (BSA) was used as the standard.

\section{Preparation of $\mathrm{OPH}$ electrodes}

MWNTs functionalized with carboxylic acid groups were dispersed in DMF and sonicated for $30 \mathrm{~min}$. A volume of $13.5 \mu \mathrm{l}$ consisting of $8 \mu \mathrm{l}$ of the enzyme solution or suspension (containing $1.22 \times 10^{-3} \mathrm{U}$ per electrode of either crude enzyme or CLEC-OPH), $2 \mu \mathrm{l}$ of MWNTs suspension, $2 \mu \mathrm{l}$ of $1 \mathrm{mg} / \mathrm{ml}$ BSA and $1.5 \mu \mathrm{l}$ of $2 \%(\mathrm{v} / \mathrm{v})$ glutaraldehyde solution, was deposited on a glassy carbon electrode after the components were mixed to homogeneity. The coating was air dried at room temperature.

\section{Apparatus}

Electrochemical measurements were performed using an Autolab PGSTAT12 Electrochemical Analyzer (EcoChemie, Utrecht, The Netherlands). The working electrode was glassy carbon (3.0 mm diameter) (BAS, Tokyo, Japan). Before each experiment, the working electrode was polished with an alumina-water slurry on cotton wool and then sonicated in distilled water. Potentials were quoted relative to the $\mathrm{Ag} / \mathrm{AgCl}$ reference (BAS). A platinum disk $(5.0 \mathrm{~mm}$ diameter) was used as the counter. All electrochemical experiments were performed in $100 \mathrm{mM}$ sodium phosphate

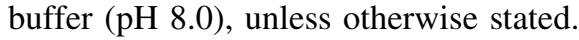

\section{Results and discussion}

Recombinant expression of $\mathrm{OPH}$ usually results in low active enzyme yield due to low solubility of this protein in E. coli (Mulbry and Karns 1989a; Grimsley et al. 1997). Though several approaches have been investigated for improved production of $\mathrm{OPH}$ in recombinant systems, including multi-gene fusions (Wu et al. 2001), fusion with highly-soluble fusion partners (Cha et al. 2000), display on cell surface (Richins et al. 1997; Li et al. 2004), and periplasmic secretion (Kang et al. 2005), reaching high productivity of OPH using E. coli-based fermentation or in other recombinant systems (Takayama et al. 2006) is still challenging, especially for further cost-efficient production of highly purified enzymes for electrochemical biosensor applications. Finding a simple alternative approach for $\mathrm{OPH}$ preparation in biosensor systems is thus of great interest.

In this work, recombinant $\mathrm{OPH}$ was predominantly expressed in inclusion form with minor fraction in active soluble form under the experimental conditions. Western blot analysis using anti-His ${ }_{6}$ antibodies showed a specific band corresponding to $\mathrm{OPH}$ in the soluble protein fraction of the recombinant $E$. coli (data not shown). The low expression yield of OPH was similar to some previous works. Nevertheless, as no background hydrolysis of organophosphate compounds was detected in the crude cell lysate of control E. coli carrying pET-32a without opd, this paved the way for the direct use of the crude enzyme from recombinant $E$. coli expressing OPH for CLEC preparation.

Cross-linked enzyme crystal technique offers a simple and economical approach for preparation of biocatalyst for biosensor application. In almost all cases, CLECs have been prepared from enzyme with high purity, mostly for organic synthesis application with very few exceptional cases where the crystalline enzymes were prepared from crude industrial enzymes (Abraham et al. 2004; Dalal et al. 2007).

\section{Characterization of CLEC-OPH}

In this work, for the first time, the catalytically active CLEC-OPH was prepared from crystallization of the crude recombinant $E$. coli cell lysate as a simple enzyme immobilization approach. OPH was crystallized by batch crystallization method. The concentration of glutaraldehyde at $1.5 \%$ for cross-linking gave catalytically active enzyme crystals. The general properties of CLEC-OPH in comparison to the crude $\mathrm{OPH}$ are given in Table 1. The specific activity of CLEC-OPH was 4-times higher than that of the crude soluble enzyme. This might be due to partial purification of the enzyme and possibly separation 
Table 1 General properties of CLEC-OPH

\begin{tabular}{|c|c|c|}
\hline Property & CLEC-OPH & Crude OPH \\
\hline $\begin{array}{l}\text { Specific activity } \\
\left(\mathrm{U}^{\mathrm{a}} \mathrm{mg} \text { protein }\right. \\
\end{array}$ & 0.542 & 0.136 \\
\hline$K_{\mathrm{m}}(\mathrm{mM})$ & 0.083 & 0.111 \\
\hline$V_{\max }\left(\mathrm{U} \mathrm{mg}^{-1}\right)$ & 0.721 & 0.168 \\
\hline$k_{\text {cat }}\left(\min ^{-1}\right)$ & 34.61 & 8.07 \\
\hline$k_{\mathrm{cat}} / K_{\mathrm{m}}\left(\mathrm{M}^{-1} \min ^{-1}\right)$ & $4.17 \times 10^{5}$ & $9.72 \times 10^{4}$ \\
\hline
\end{tabular}

${ }^{a} \mathrm{U}$ defined as $\mu \mathrm{mol} \mathrm{min}^{-1}$; using paraoxon as substrate for pesticide hydrolysis by $\mathrm{OPH}$

of inhibitory substances in the ammonium sulfate precipitation step.

Kinetic parameters were determined using the Michaelis-Menten equation from a Hanes-Woolf plot. For CLEC$\mathrm{OPH}$, the Michaelis-Menten constant $K_{\mathrm{m}}$ was $0.083 \mathrm{mM}$ $( \pm 0.0056 \mathrm{SD}, n=3)$ and the maximum velocity $V_{\max }$ was $0.721 \mathrm{U} \mathrm{mg}^{-1}$ crystal protein $( \pm 0.0344 \mathrm{SD}, n=3)$. Compared to the crude soluble enzyme, the crystalline enzyme had increased $V_{\max }$ and slightly higher affinity to the substrate. This led to an improved catalytic constant $k_{\text {cat }}$ and hence, a 4.3-fold increase in catalytic efficiency, $k_{\mathrm{cat}} / K_{\mathrm{m}}$. Typically, immobilized enzymes exhibit an increased $K_{\mathrm{m}}$ relative to the solution value. However, the apparent $K_{\mathrm{m}}$ obtained from CLEC-OPH was not significantly increased. This agrees with results obtained from CLEC formed from pancreatic acetone powder (Dalal et al. 2006) and pectinase, xylanase and cellulase (Dalal et al. 2007). This was attributed by the authors to the enzyme aggregation in CLEC and to the presence of an open structure in which mass transport of substrate was similar to that at the soluble enzyme, when low concentrations of glutaraldehyde were used (Dalal et al. 2007). Meanwhile, $V_{\max }$ for CLEC-OPH was far greater than for the soluble form. This is probably due to partial purification of the enzyme by protein fractionation in the precipitation step resulting in higher enzyme specific activity. This has also been observed in the case of CLEC containing pectinase, xylanase and cellulase (Dalal et al. 2007) and glucoamylase (Abraham et al. 2004). Hence, the catalytic enzyme rate constant $k_{\text {cat }}$ and the catalytic efficiency, which is related to $V_{\max }$, were higher than in the soluble crude $\mathrm{OPH}$.

Thermostability of CLEC-OPH was remarkably improved when compared to the soluble enzyme (Fig. 1). Pre-incubation of CLEC-OPH and crude OPH at $40^{\circ} \mathrm{C}$ led to activation of the enzyme activity, with $147 \%$ activity increase observed for CLEC-OPH after incubation for $4 \mathrm{~h}$. At higher temperatures, from $50^{\circ} \mathrm{C}$, the thermal inactivation of the crude enzyme became more pronounced and complete loss of activity was observed after incubation at $60^{\circ} \mathrm{C}$ for $1 \mathrm{~h}$. In contrast to the crude enzyme, CLEC-OPH retained full activity at temperature up to $55^{\circ} \mathrm{C}$. Gradual inactivation of the microcrystalline enzyme was observed at $60^{\circ} \mathrm{C}$ and $43 \%$ of the catalytic activity was retained after incubation for $4 \mathrm{~h}$. Activation of CLEC's catalytic activity by pre-incubation at elevated temperatures was previously reported in microcrystalline glucoamylase (Abraham et al. 2004). The remarkable enhancement of thermostability in CLEC-OPH would be due to stabilization of the catalytically active conformation of the enzyme by chemical crosslinking of OPH with the heterogeneous proteins in the crystal lattice, resulted from the inter- and intramolecular interactions which led to increased rigidity of the threedimensional conformation of molecules in CLECs (Roy and Abraham 2004).

\section{Application of CLEC-OPH in electrochemistry}

\section{Optimization of CLEC-OPH amperometric biosensor}

As the first step in CLEC application on electrochemical biosensor, the detection conditions and parameters were optimized. Using the electrode modification procedure described in the experimental section, we examined the effect on the electrode response to varying mass of CLECOPH. The optimum CLEC-OPH-loading was found to be
Fig. 1 Thermostability of crude OPH (a) and CLEC-OPH (b) at $40-60^{\circ} \mathrm{C}$ for $(\square) 1 \mathrm{~h},(\square) 2 \mathrm{~h}$, and $(\square) 4 \mathrm{~h}$
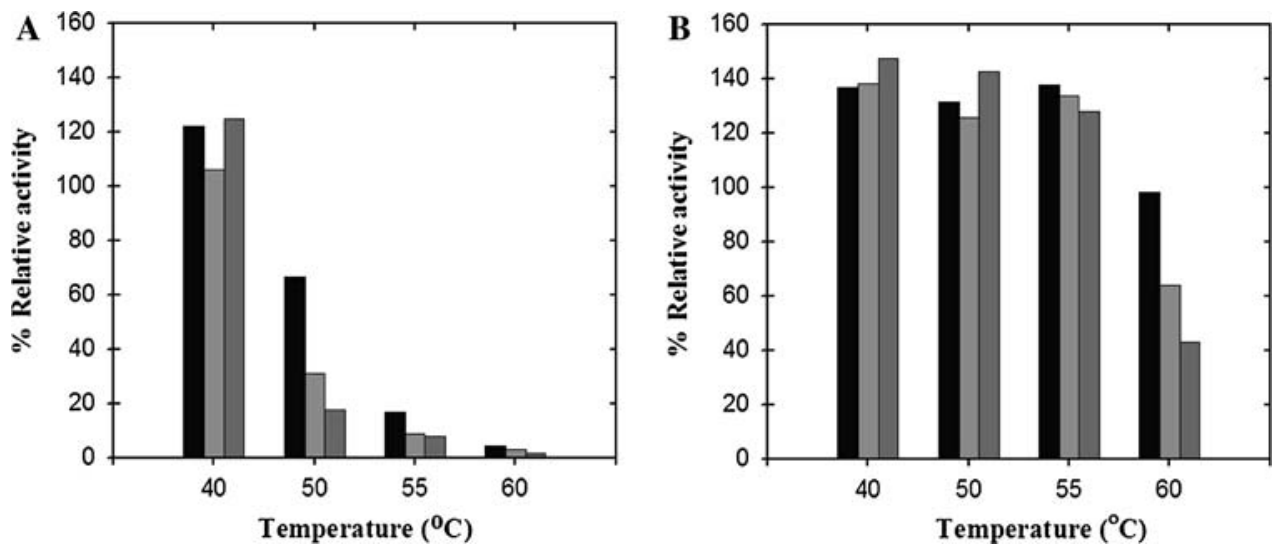
$5 \mathrm{mg}$ crystal per electrode (Fig. 2a). Increasing the crystal beyond $5 \mathrm{mg}$ resulted in a decreased paraoxon signal, presumably because the increased density of CLEC caused a barrier for diffusion of $p$-nitrophenol to the electrode.

MWNTs were used to promote the oxidation of phenolic compounds and to minimize surface fouling (Wang 2005; Balasubramanian and Burghard 2006). The MWNTs were co-immobilized with the CLEC-OPH based on previous reports in which CNTs incorporated with adsorbed enzyme on an electrode resulted in enhanced sensitivity (Joshi et al. 2005). The mass of the MWNTs incorporated was also examined. The sensitivity increased slightly upon raising the MWNTs loading between 0.10 and $1.25 \mathrm{mg} / \mathrm{ml}$ and decreased rapidly thereafter (Fig. 2b). The initial increase in MWNTs represents an increased surface area for $p$-nitrophenol reaction, whereas a very high mass of MWNTs may obstruct analyte diffusion to the enzyme.

To determine the appropriate potential for $p$-nitrophenol oxidation, hydrodynamic voltammetry was performed. Figure 3 shows the current response of the electrode using different concentrations of paraoxon at different applied potentials. It can be seen that the current responses were independent to potential between 0.90 and $0.95 \mathrm{~V}$, and then at $>0.95 \mathrm{~V}$ rising currents were observed. This was unlikely to be due to water hydrolysis since no gas bubbles
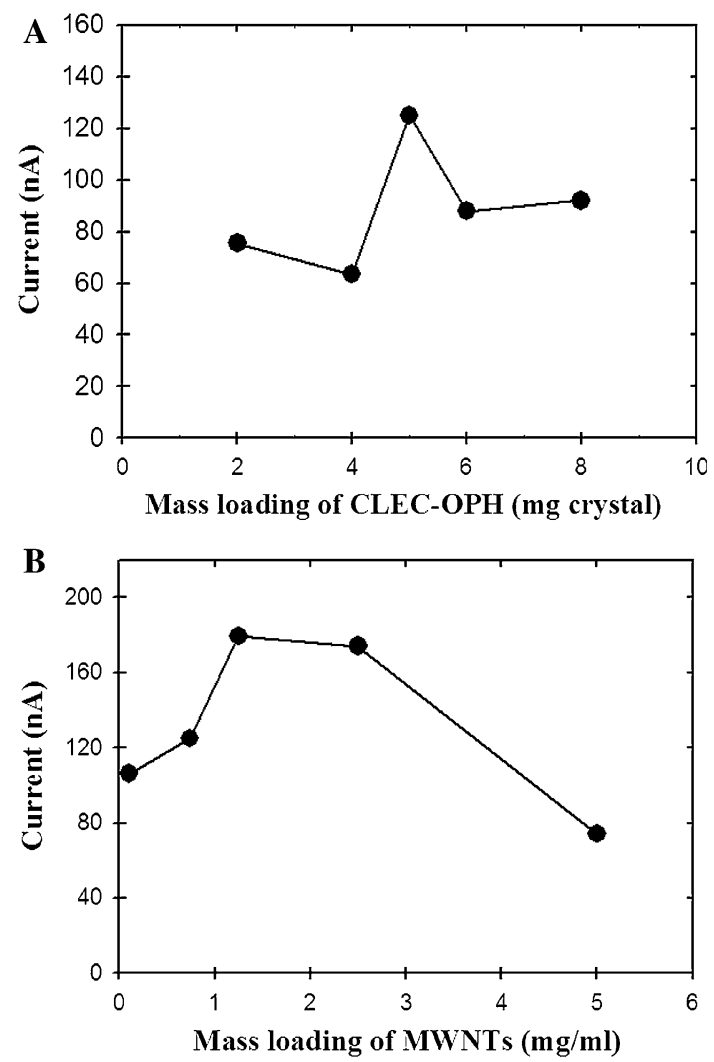

Fig. 2 Amperometric current at $0.95 \mathrm{~V}$ versus $\mathrm{Ag} / \mathrm{AgCl}$ to $19.77 \mu \mathrm{M}$ paraoxon at varying amount of CLEC-OPH (a) and MWNT (b) were observed. It may be due to the direct electrochemical oxidation of paraoxon, which has been reported previously at approximately this potential (Mulchandani et al. 1999a). On the basis of this result, the applied potential was set at $0.95 \mathrm{~V}$ for further work.

The effect of $\mathrm{pH}$ on the response of the CLEC-OPH electrode to paraoxon was evaluated in $100 \mathrm{mM}$ sodium phosphate buffer ( $\mathrm{pH} 7.0-\mathrm{pH} 8.0)$ and $100 \mathrm{mM}$ glycine$\mathrm{NaOH}$ (pH 9.0-pH 10.0) (Fig. 4). The electrode performed best at $\mathrm{pH}$ 8.0. This is a similar result to previous reports examining immobilized $\mathrm{OPH}$ in the range $\mathrm{pH} 7.0-\mathrm{pH} 8.5$ (Mulchandani et al. 1999a; Chough et al. 2002; Wang et al. 2003; Deo et al. 2005).

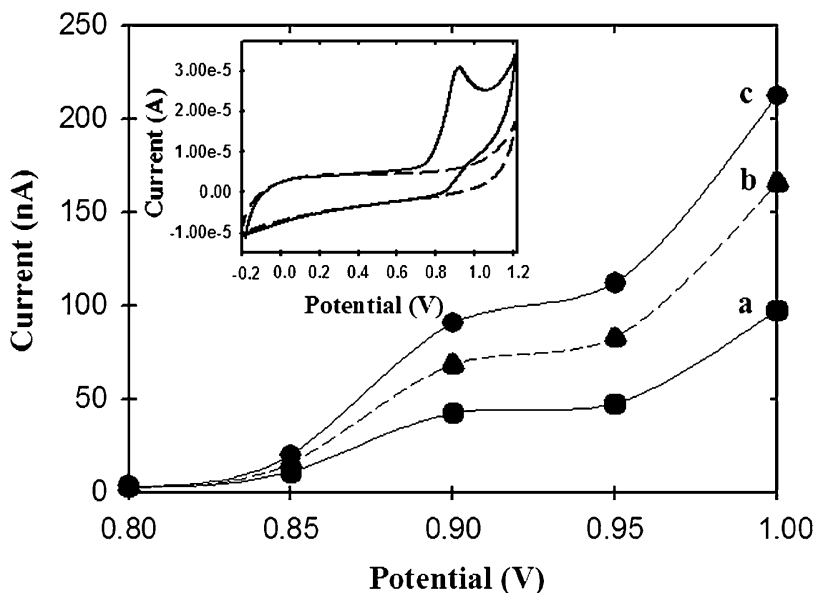

Fig. 3 Hydrodynamic voltammograms of paraoxon at (a) $3.32 \mu \mathrm{M}$ (b) $6.63 \mu \mathrm{M}$ and (c) $9.93 \mu \mathrm{M}$ at a CLEC-OPH electrode. Inset: Cyclic voltammogram at a scan rate of $0.1 \mathrm{~V} \mathrm{~s}^{-1}$ : in the absence (-) and presence of $1 \mathrm{mM} p$-nitrophenol (-- -)

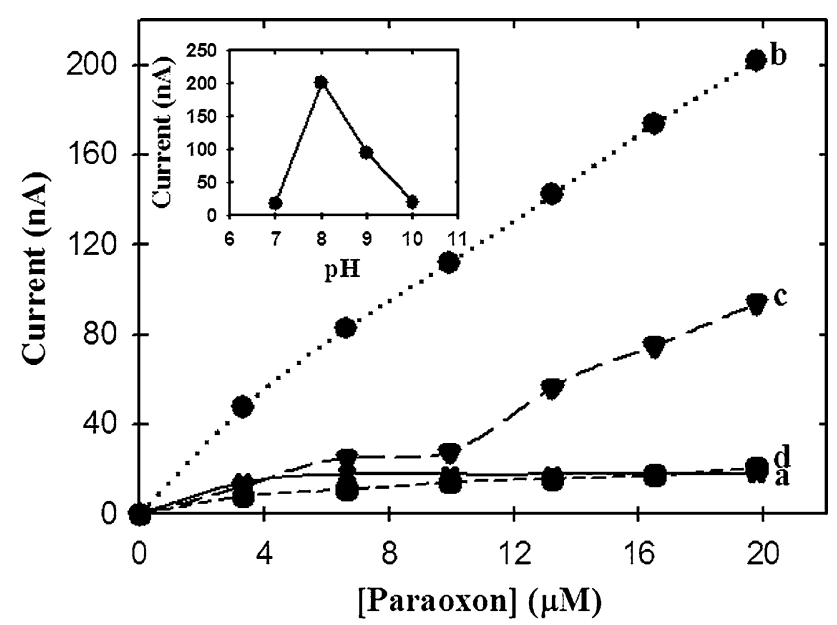

Fig. 4 Effect of $\mathrm{pH}$ on amperometric response of the CLEC-OPH electrode at $0.95 \mathrm{~V}$ versus $\mathrm{Ag} / \mathrm{AgCl}$ in sodium phosphate buffer at (a) $\mathrm{pH}$ 7.0, and (b) $\mathrm{pH}$ 8.0, and glycine-NaOH buffer at (c) $\mathrm{pH} 9.0$, and (d) $\mathrm{pH}$ 10.0. The inset shows $\mathrm{pH}$ against the responses 


\section{Analytical characterization of CLEC-OPH biosensor}

An electrode modified with the OPH crystal was compared to one modified with the non-crystal form. The latter was immobilized by glutaraldehyde cross-linking of the crude OPH under the same conditions and enzyme unit activity. Figure 5 in inset A displays calibration plots for paraoxon at the CLEC-OPH electrode, and the crude OPH electrode is illustrated in inset $\mathrm{B}$. The sensitivity for the CLEC-OPH electrode over the $0.5-2.5 \mu \mathrm{M}$ range was $25.95 \mathrm{nA} / \mu \mathrm{M}$, which is ca. 1.5-fold greater than the crude OPH electrode (Table 2). Partition of paraoxon into the two enzyme films can be compared by noting the apparent $K_{\mathrm{m}}$ values. As expected, $K_{\mathrm{m}}$ for the CLEC-OPH electrode was slightly higher than for the crude OPH film $(6.19 \mu \mathrm{M}$ cf. $5.16 \mu \mathrm{M})$, suggesting a lower degree of substrate partition into the crystal film.

Note the immobilized CLEC-OPH and crude OPH electrodes exhibited far lower $K_{\mathrm{m}}$ values than the enzyme in bulk solution ( $K_{\mathrm{m}}$ evaluated from absorbance of $p$-nitrophenolate). This result may indicate a high substrate concentration close to the enzyme electrode due to

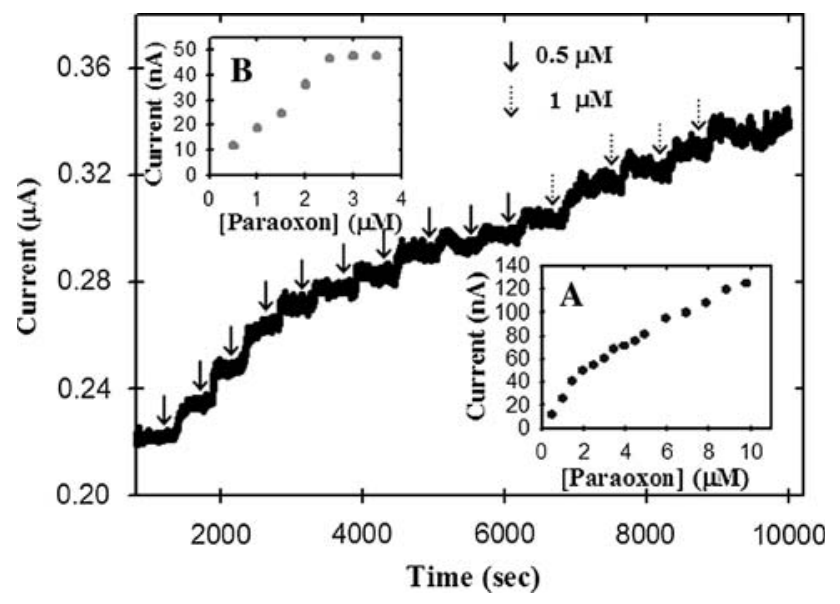

Fig. 5 Amperometric responses of paraoxon at a CLEC-OPH electrode. Arrows refer to adding points. Inset A: Calibration at the CLEC-OPH electrode and inset B represents the crude OPH electrode. Both electrode responses were obtained by using $1.22 \times 10^{-3} \mathrm{U}$ of enzyme

Table 2 Electrochemical detection performance of CLEC-OPH electrode and crude-OPH electrode

\begin{tabular}{lll}
\hline Property & $\begin{array}{l}\text { CLEC-OPH } \\
\text { electrode }\end{array}$ & $\begin{array}{l}\text { Crude OPH } \\
\text { electrode }\end{array}$ \\
\hline Sensitivity $\left(\mathrm{nA} \mu \mathrm{M}^{-1}\right)$ & 25.95 & 17.29 \\
Linear range $(\mu \mathrm{M})$ & $0.50-2.00$ & $0.50-2.50$ \\
Detection limit $(\mu \mathrm{M})$ & 0.314 & 0.500 \\
\hline
\end{tabular}

favorable substrate adsorption to either the CLEC/crude enzyme surface or to the electrode surface. For the general enzyme process:

$\mathrm{E}+\mathrm{S} \underset{k_{-1}}{\stackrel{k_{1}}{\rightleftharpoons}} \mathrm{ES} \stackrel{k_{\text {cat }}}{\longrightarrow} \mathrm{E}+\mathrm{P}$

$K_{\mathrm{m}}$ is defined as $\left(k_{-1}+k_{\text {cat }}\right) / k_{1}$. Hence, if the substrate concentration at the enzyme is higher than the substrate concentration in bulk solution the rate of the reaction $\mathrm{E}+\mathrm{S} \rightarrow \mathrm{ES}$ will be increased, giving a larger value of $k_{1}$. Therefore the value of $K_{\mathrm{m}}$ will be lower. The value $i_{\max }$ is proportional to the maximum reaction rate $\left(V_{\max }=k_{\text {cat }} E_{\mathrm{T}}\right)$. From the experiment, $i_{\max }$ for the CLEC-OPH electrode was greater than the crude OPH (189.23 nA cf. $127.04 \mathrm{nA})$, despite a lower degree of partitioning. This emphasizes the high catalytic activity provided by the crystal lattice. The limit of detection (3 times the standard deviation of the response obtained for a blank) was $0.314 \mu \mathrm{M}$ at the CLEC$\mathrm{OPH}$ electrode, and $0.5 \mu \mathrm{M}$ for the cross-linked $\mathrm{OPH}$ electrode. For repeated uses in batch a measurement, the sensor response of the CLEC-OPH based electrode decreased gradually after sixteen successive assays of 0.5 and $1 \mu \mathrm{M}$ paraoxon (Fig. 5) compared to that of the electrode using crude $\mathrm{OPH}$ of which the sensor response stopped after five assays. The result thus, indicated the higher operational stability of the CLEC-based biosensor. The marked improvement in operational stability of CLEC-OPH, compared to the soluble enzyme would be related to the more extensive interactions in stabilization of enzyme's active conformation in the crystalline structure by intra-/ intermolecular interactions (Roy and Abraham 2004). The result would thus indicate an additional advantage of CLECs in electrochemical biosensor application. The biocatalytic activity of CLEC-OPH was maintained over a prolonged period of at least 3 months (keeping at $10^{\circ} \mathrm{C}$ ), reflecting the storage stability of the enzyme.

\section{Conclusions}

In conclusion, an amperometric biosensor for paraoxon has been developed by the use of crude enzyme-based CLECs, which provide a simple route to constructing biosensors using crude rather than the costly purified OPH. The resulting biosensor exhibited a sensitivity similar to some previous reports on paraoxon measurement by amperometric biosensors using purified OPH, including the one of the highest reported sensitivity $(25.95 \mathrm{nA} / \mu \mathrm{M}$ cf. $25 \mathrm{nA} / \mu \mathrm{M})$ but showed a slightly higher limit of detection $(0.314 \mu \mathrm{M}$ cf. $0.150 \mu \mathrm{M}$ ) (Deo et al. 2005). The developed CLEC-OPH biosensor could possibly be improved by lowering the electrical noise of the hardware. The use of the crude enzyme in CLEC form may thus lead to the development of 
OPH-based biosensors of an economically viable production cost.

Acknowledgement T. Laothanachareon gratefully acknowledges "Toon-Songserm-Withayanipon" studentship from KMUTT.

Open Access This article is distributed under the terms of the Creative Commons Attribution Noncommercial License which permits any noncommercial use, distribution, and reproduction in any medium, provided the original author(s) and source are credited.

\section{References}

Abraham TE, Joseph JR, Bindhu LBV, Jayakumar KK (2004) Crosslinked enzyme crystals of glucoamylase as a potent catalyst for biotransformations. Carbohydr Res 339:1099-1104

Balasubramanian K, Burghard M (2006) Biosensors based on carbon nanotubes. Anal Bioanal Chem 385:452-468

Cha HJ, Wu CF, Valdes JJ, Rao G, Bentley WE (2000) Observations of green fluorescent protein as a fusion partner in genetically engineered Escherichia coli: monitoring protein expression and solubility. Biotechnol Bioeng 67:565-574

Chough SH, Mulchandani A, Mulchandani P, Chen W, Wang J, Rogers KR (2002) Organophosphorus hydrolase-based amperometric sensor: modulation of sensitivity and substrate selectivity. Electroanalysis 14:273-276

Dalal S, Kapoor M, Gupta MN (2006) Preparation and characterization of combi-CLEAs catalyzing multiple non-cascade reactions. J Mol Catal B Enzyme 44:128-132

Dalal S, Sharma A, Gupta MN (2007) A multipurpose immobilized biocatalyst with pectinase, xylanase and cellulase activities. Chem Cent J 1:16

Deo RP, Wang J, Block I, Mulchandani A, Joshi KA, Trojanowicz M, Scholz F, Chen W, Lin Y (2005) Determination of organophosphate pesticides at a carbon nanotube/organophosphorus hydrolase electrochemical biosensor. Anal Chim Acta 530: 185-189

Dumas DP, Cald well SR, Wild JR, Raushel SB (1989) Purification and properties of the phosphotriesterase from Pseudomonas diminuta. J Biol Chem 264:19659-19665

Grimsley JK, Scholtz JM, Pace CN, Wild JR (1997) Organophosphorus hydrolase is a remarkably stable enzyme that unfolds through a homodimeric intermediate. Biochemistry 36:1436614374

Joshi PP, Merchant SA, Wang Y, Schmidtke DW (2005) Amperometric biosensors based on redox polymer-carbon nanotubeenzyme composites. Anal Chem 77:3183-3188

Kang DG, Lim GB, Cha HJ (2005) Functional periplasmic secretion of organophosphorus hydrolase using the twin-arginine translocation pathway in Escherichia coli. J Biotechnol 118:379-385

Li L, Kang DG, Cha HJ (2004) Functional display of foreign protein on cell surface of Escherichia coli using N-terminal domain of ice nucleation protein. Biotechnol Bioeng 85:214-221

Margolin AL, Navia MA (2001) Protein crystals as novel catalytic materials. Angew Chem Int Ed 40:2204-2222

Mattos IL, Lukachova LV, Gorton L, Laurell T, Karyakin AA (2001) Evaluation of glucose biosensors based on Prussian Blue and lyophilized, crystalline and cross-linked glucose oxidase $\left(\right.$ CLEC $\left.^{\circledR}\right)$. Talanta 54:963-974

Mulbry WW, Karns JS (1989a) Parathion hydrolase specified by the Flavobacterium opd gene: relationship between the gene and protein. J Bacteriol 171:6740-6746

Mulbry WW, Karns JS (1989b) Purification and characterization of three parathion hydrolases from gram-negative bacterial strains. Appl Environ Microbiol 55:289-293

Mulchandani A, Mulchandani P, Chen W, Wang J, Chen L (1999a) Amperometric thick-film strip electrodes for monitoring organophosphate nerve agents based on immobilized organophosphorus hydrolase. Anal Chem 71:2246-2249

Mulchandani A, Pan S, Chen W (1999b) Fiber-Optic Biosensor for direct determination of organophosphate nerve agents. Biotechnol Prog 15:130-134

Mulchandani P, Mulchandani A, Kaneva I, Chen W (1999c) Biosensor for direct determination of organophosphate nerve agents. 1. potentiometric enzyme electrode. Biosens Bioelectron 14:77-85

Mulchandani P, Chen W, Mulchandani A (2001) Flow injection amperometric enzyme biosensor for direct determination of organophosphate nerve agents. Environ Sci Techonol 35:2562-2565

Navia MA, St Clair NL (1999) Biosensor, extracorporeal devices and methods for detecting substances using cross-linked protein crystals. U.S. Patent $6,004,768$

Rajan A, Abraham TE (2007) Studies on crystallization and crosslinking of lipase for biocatalysis. Bioprocess Biosyst Eng: DOI 10.1007/s00449-007-0149-5

Richins RD, Kaneva I, Mulchandani A, Chen W (1997) Biodegradation of organophosphorus pesticides by surface-expressed organophosphorus hydrolase. Nat Biotechnol 15:984-987

Rogers KR, Wang Y, Mulchandani A, Mulchandani P, Chen W (1999) Organophosphorus hydrolase-based assay for organophosphate pesticides. Biotechnol Prog 15:517-521

Roy JJ, Abraham TE (2004) Strategies in making cross-linked enzyme crystals. Chem Rev 104:3706-3721

Roy JJ, Abraham ET (2006) Preparation and characterization of cross-linked enzyme crystals of laccase. J Mol Catal B: Enzym 38:31-36

Roy JJ, Abraham TE, Abhijith KS, Sujith Kumar PV, Thakur MS (2005) Biosensor for the determination of phenols based on cross-linked enzyme crystals (CLECs) of laccase. Biosens Biotectron 21:206-261

Simonian AL, Good TA, Wang SS, Wild JR (2005) Nanoparticlebased optical biosensors for the direct detection of organophosphate chemical warfare agents and pesticides. Anal Chimica Acta 543:69-77

Takayama K, Suye S, Kuroda K, Ueda M, Kitaguchi T, Tsuchiyama K, Fukuda T, Chen W, Mulchandani A (2006) Surface display of organophosphorus hydrolase on Saccharomyces cerevisiae. Biotechnol Prog 22:939-943

Wang J (2005) Carbon-nanotube based electrochemical biosensors: A review. Electroanalysis 7:7-14

Wang J, Krause R, Block K, Musameh M, Mulchandani A, Schoning MJ (2003) Flow injection amperometric detection of OP nerve agents based on an organophosphorus-hydrolase biosensor detector. Biosens Bioelectron 18:255-260

Wu CF, Valdes JJ, Rao G, Bentley WE (2001) Enhancement of organophosphorus hydrolase yield in Escherichia coli using multiple gene fusions. Biotechnol Bioeng 75:100-103 